\title{
The Spiritual Dimension of Social Pedagogy The View through the Eyes of Students at Sts Cyril and Methodius Faculty of Theology, Palacký University Olomouc Petra Potměšilová
}

\begin{abstract}
:
Social Pedagogy, a study programme at Sts Cyril and Methodius Faculty of Theology, has its specifics. During studies, the emphasis is on the development of values that are accentuated in the Christian tradition. This specificity is fully in line with one of the theoretical pillars of social pedagogy (solidarity, helping others). The aim of the research was to focus on the students' perspective concerning the potential importance of the spiritual overlap of the Social Pedagogy programme. The main research method was a questionnaire containing ten questions. The results were processed using IBM SPSS 21 and 23. Descriptive statistics were used. The T-test for two independent samples, Analysis of variance (ANOVA), the Kruskal-Wallis test, and the Pearson correlation coefficient were used to verify the hypotheses. The results have shown that the students perceive the spiritual dimension of the Social Pedagogy programme positively. In this perception, also important was the fact whether faith is relevant to them personally in their lives, and the year of their studies.
\end{abstract}

\section{Keywords:}

social pedagogy, study programme, spiritual dimension, solidarity, faith

\section{Introduction}

Social pedagogy is one of the disciplines which can be classified as humanities, and it is among those defined as helping ones. Defining social pedagogy is not as easy as it would seem. Kraus ${ }^{1}$ argues that the definition of social pedagogy has changed over time in the context of a change in the concept of 'social': from the need to help those who have found themselves in a difficult life situation to a relationship with society as a whole (that is, in the sense of educating all social categories for life in a given society). These two concepts of social pedagogy have stabilised in the Czech Republic and correspond to the focus of individual study programmes.

One of the possibilities where Social Pedagogy can be studied in the Czech Republic is Sts Cyril and Methodius Faculty of Theology at Palacký University Olomouc. In this context, there are often questions from the educated public about the differences in the concept of social pedagogy at Sts Cyril and Methodius Faculty of Theology, and about the legitimisation of this field at the

1 Bohuslav KRAUS, Základy sociální pedagogiky, Praha: Portál, 2008, p. 39. 
theological faculty. These questions and the statements of students that were randomly recorded during 2009-2019 (see text below - Chapter 4) resulted in the intention to carry out a research project. Its aim was to find the answer to the basic questions whether and how these studies differ from study programmes at other universities in the Czech Republic, and if and how students perceive this potential differentiation.

\section{Theoretical Anchoring}

The roots of social pedagogy can be found in Germany when Karl Mager first used the term social pedagogy in 1844 (in connection with the need to link education and social reality). ${ }^{2}$ Adolph Diesterweg then shifted the notion of social pedagogy to social policy, emphasising the need to help (both in material and educational ways) individuals in need. ${ }^{3}$ Gottschalk ${ }^{4}$ states that until the beginning of the 20th century, the concept of social pedagogy in Germany was developing. Many influences, such as moral philosophy, epistemology, and various social theories, were involved in the debate over the concept. Currently, social pedagogy is (according to Sünker and Braches-(hyrek ${ }^{5}$ ) understood as a scientific context where an individual is able to evolve himself and change his life situation based on the educational process. Noack ${ }^{6}$ subsequently states that social pedagogy is almost identical to social work, however, unlike social work, it focuses on education as well (in addition to professional care). Öbrink Hobzová ${ }^{7}$ writes about the specific relationship between social pedagogy and social work in her book Sociální pedagogika a její metody. In a certain sense, these disciplines may partly overlap as both can help to change an individual's life situation. However, social pedagogy shifts problems, and therefore its work is with the individual, more in educational situations. In this way it differs from social work.

Social education has gradually spread from Germany to other countries. In the Czech Republic, social pedagogy has had a tradition since the $19^{\text {th }}$ century. The authors Kraus ${ }^{8}$ and Procházka ${ }^{9}$ both consider Adolf Lindner to be the founder of social pedagogy. Lindner was a professor of pedagogy at Charles University in Prague. Over time, social pedagogy in the Czech Republic has established itself both in practical use and as a scientific discipline. Kraus ${ }^{10}$ summarises five basic areas of importance that form the framework of social pedagogy: the object of education (education is aimed at whole social groups, not individuals), forms and conditions of education (extracurricular institutions, local environment), education goals (social needs, cooperation, altruism...), methods of education (indirect educational procedures), and a sense of social help (solidarity with the needy). An interesting definition of social pedagogy is given by Bakošová. ${ }^{11}$ She perceives social pedagogy as a life aid, that is, a kind of complex care for children, youth,

2 Cf. Juha HÄMÄLÄINEN, Social Pedagogy as a Scientific Discipline - a Branch of Academic Studies and a Field of Professional Practice, EccoS-Revista Científica 48/2019, pp. 17-34.

3 Cf. Franz HAMBURGER, Sozialpädagogik in Deutschland. Eine Darstellung aus der Perspektive erziehungswissenschaftlicher Tradition, Journal of Contemporary Educational Studies 3/2014, pp. 14-30.

4 Cf. Gerhard Michael GOTTSCHALK, Entstehung und Verwendung des Begriffs Sozialpädagogik. Extrapolation systematischer Kategorien als Beitrag für das Selbstverständnis heutiger Sozialpädagogik. Eichstätter Sozialpädagogische Arbeiten, Eichstätt: BPB-Verl., 2004.

5 Heinz SÜNKER and Rita BRACHES-CHYREK, Social pedagogy in Germany, in: The diversity of social pedagogy in Europe, ed. Jacob KORNBECK and Niels Rosendal JENSEN, Bremen: Europäischer Hochschulverlag, 2009, p. 18.

6 Winfried NOACK, Sozialpädagogik: ein Lehrbuch, Freiburg im Breisgau: Lambertus, 2011, p. 26.

7 Cf. Milena ÖBRINK HOBZOVÁ, Metody v disciplínách blízkých sociální pedagogice, in: Sociální pedagogika a její metody, Petra SOBKOVÁ et al., Olomouc: UP, 2015, pp. 25-28.

8 Cf. KRAUS, Základy..., p. 11.

9 Cf. Miroslav PROCHÁZKA, Sociální pedagogika, Praha: Grada, 2012, p. 54.

10 Cf. ibid., p. 40.

11 Cf. Zlatica BAKOŠOVÁ et al., Sociálna pedagogika, Bratislava: Slovenské pedagogické nakladatel'stvo, 2005, p. 47. 
and adults in various types of environments and attributes four basic goals to it: ${ }^{12}$ clarification of relationships between education and the environment, educational intervention and legal requirements for education, understanding education as an aid to all age categories of clients, and study and intervention in the field of deviations of social behaviour.

In the introduction, the current dual concept of social pedagogy in the Czech Republic was mentioned. Kraus and Poláčková ${ }^{13}$ present a broader concept of social pedagogy, that is, creating balance between the needs of individuals and society, which is contributing to an optimal way of life at a given time and given social conditions. A narrower concept of social pedagogy is characterised by Matoušek, ${ }^{14}$ who sees the essence of social pedagogy in the process of recognising social factors which can threaten human development, and in applying procedures that counterbalance their adverse effects. Rajský ${ }^{15}$ states that the core of education should be the ability which helps to liberate human nature from various empirical determinants and ensures the achievement of personal and social fullness. This general purpose of pedagogy is enhanced and given priority in social pedagogy. According to Procházka, ${ }^{16}$ social pedagogy is based on two basic pillars: philosophical thinking (which focuses on statements about the relationship between society and man), and on social work (in the form of care, solidarity, and concern for others).

Whether social pedagogy is perceived as a discipline with a target group consisting of individuals at risk or as a discipline that deals with the general impact of the environment on the upbringing of an individual, there are common points in both concepts, especially the above mentioned help, solidarity, or concern for others.

But why does social pedagogy belong to the humanities? Foucault ${ }^{17}$ states that each of the humanities originated in the occasion of a problem, a requirement, an obstacle to a theoretical or practical order. He also states that human sciences are based on three pillars, namely biology, economics, and the study of speech. In the field of biology, it is the ability to find average standards of adaptation to existential conditions. In terms of economics, it is an attempt to satisfy one's own interests. In terms of the study of speech, it is the importance of human behaviour. ${ }^{18}$ Based on the interconnection of the above, it can be stated that the humanities core of social pedagogy is an educational effect on man in terms of help and solidarity, that is, a kind of charity or doing good to others. Help, solidarity, or doing good are hardly measurable actions to which individuals are led or not led to by upbringing, by a state of society, and that are also significantly related to the spiritual area of life.

An example of the social impact on the development of solidarity is the declaration of the World Day of Social Justice, which was declared by the United Nations (UN) in 2007. ${ }^{19}$ The aim of this day is to highlight important issues such as the poverty eradication, respect for human rights, and education leading to equality and mutual respect. In connection with doing good, it is worth mentioning love, which is perceived as an essential variable in aid and charity. Based on Max Scheller's theory, Pelcová ${ }^{20}$ states that love makes us receptive and open, while hatred closes us,

2 Cf. ibid., p. 19.

13 Cf. Blahoslav KRAUS et al., Člověk - prostředí - výchova: k otázkám sociální pedagogiky, Brno: Paido, 2001, p. 12.

14 Cf. Oldřich MATOUŠEK et al., Metody a řízení sociální práce, Praha: Portál, 2003, p. 210.

15 Cf. (C) Andrej RAJSKÝ, What's Wrong in Modern Education? Maritain's Warning is Valid Today More than Ever, Caritas et Veritas 2/2018, p. 60. Available at: http://www.caritasetveritas.cz/index.php?action=openfile\&pkey=279, cited $23^{\text {rd }}$ May 2019.

16 Cf. PROCHÁZKA, Sociální..., p 11.

17 Cf. Michael FOUCAULT, Slova a věci, Brno: Computer Press, a.s., 2007, p. 264.

18 Cf. ibid., p. 273.

19 (C) Organizace spojených národů. Available at: https://www.osn.cz/events/event/svetovy-den-socialni-spravedlnosti-2016-02-20/, cited $11^{\text {th }}$ May 2019.

20 (c) Naděžda PELCOVÁ and Ilona SEMERÁDOVÁ, Fenomén výchovy a etika učitelského povolání, Praha: Karolinum Press, 2014. Available 
encapsulates us, and condemns us to isolation, narcissism, and individualism. The author thus shifts the topic of 'help' further and points out that love is not only the essence of receptivity and openness to others: it can retrospectively bring good feelings to the individual as well. Šarníková ${ }^{21}$ understands love in accordance with Maslow's theory as a need, and claims that when a child lacks love, he not only lacks the need to receive but also the need to give. This dimension is key in the profession of social educator.

In the context of the spiritual dimension of help, doing good and showing love cannot be overlooked in Bible. Jesus urges people to help each other: Do to others as you would have them do to you. (Lk 6:31). However, Jesus continues and adds that there is nothing special about this, that the essence of selfless help and doing good is... to love our enemies; to do well, to lend and expect nothing back ... to be as merciful as Father is (Lk 6:35-36). In the Letter to the Romans (Romans 13:10) the following statement can be found: Love does no harm to a neighbour. Throughout the Bible, God's existence is associated with love: Whoever does not love does not know God, because God is love. (1Jn 4:8). All of these passages from the Bible thus correspond to the basic mission of social pedagogy - help, doing good. They also supplement it with spiritual values, that is, selflessness, love, and an anchoring in love for God. In addition to the Bible, we can also turn to the papal documents $^{22}$ that have been written since the 19th century and which, with varying intensity, are dedicated to the dignified position of man in the world. The social doctrine of the $\mathrm{Church}^{23}$ has become an important part of the Church's teaching and is still accentuated in the documents and speeches of the present pope. ${ }^{24} \mathrm{~A}$ concrete example is the social encyclical Deus caritas est ${ }^{25}$ where the relationship of love to God and neighbour is described in detail as outlined above.

\section{The Social Pedagogy Programme at Sts Cyril and Methodius Faculty of Theology}

In the Czech Republic it is possible to study social pedagogy at several different universities. Despite the differences in the conception of individual study programmes, they are within the abovementioned range of social pedagogy. In 2017, the Association of Social Pedagogy Educators published the Standards for Social Pedagogy Education. ${ }^{26}$ These standards include the basic thematic frameworks of study and the graduate's general profile - possible employment opportunities and relevant professions.

The Social Pedagogy Programme at Sts Cyril and Methodius Faculty of Theology is based on a broader concept of social pedagogy and the curriculum meets the abovementioned standards. However, the graduate's profile also mentions that, due to the focus of Sts Cyril and Methodius Faculty of Theology, emphasis will be placed on the development of values and principles accented in the Christian tradition and their use in the educational process. ${ }^{27}$ When developing

at: http://search.ebscohost.com/login.aspx?direct=true\&db=nlebk\&AN=1107667\&lang=cs\&site=eds-live, cited 10 $0^{\text {th }}$ May 2019 , pp. 84-85.

21 Cf. Gabriela ŠARNÍKOVÁ, Život v spoločenstve - láska či prosociálnost??, In: Edukacja. Działania społeczne. Rodzina, Wiesław WÓJCIK and Erika LALÍKOVÁ, Bielsko-Biała: Wydawnictwo Akademii Techniczno-Humanistycznej, 2008, pp. 37-43.

22 For example, Rerum novarum (1892), Quadragesimo anno (1941), Mater et magistra (1961), Pacem in terris (1961), Documents of the Second Vatican Council such as Gaudium et spes (1965) or Dignitatis humanae (1965), the social encyclicals of John Paul II or Caritas in veritate (2009) by Benedict XVI.

23 In more detail, for example, Kompendium sociální nauky církve, Kostelní Vydř́: Karmelitánské nakladatelství, 2008.

24 Laudato si (2015).

25 Deus caritas est, articles 16-18.

26 두 Asociace vzdělavatelů v sociální pedagogice, Standardy vzdělávání v oblasti sociální pedagogiky. Available at: http://asocped.cz/ folders-1305/, cited $12^{\text {th }}$ May 2019.

27 Cf. Marcela FOJTÍKOVÁ ROUBALOVÁ, Duchovní rozměr sociálního pedagoga, in: Sociální pedagogika $v$ teorii a praxi, Petra 
the concept of the study programme, two basic areas were identified. These are meant to enrich the curriculum and take into account the aforementioned declaration. The first is to incorporate specific subjects that focus on the perception of values and the spiritual dimension of man, and to enrich all subjects with a Christian perspective on the issue. The second is the personal example and testimony of academic staff.

In the case of the theoretical enrichment of the curriculum, the Christian roots of culture and their impact on education are emphasised. The Ten Commandments of God and its effect (not only on legal systems, but, above all, on the sensing of morality and the subsequent influence on education) can serve as an example. An interesting reference to responsible education can be found in the New Testament: No discipline seems pleasant at the time, but painful. Later on, however, it produces a harvest of righteousness and peace for those who have been trained in it. (Heb 12:11). Another example related to Christian roots and values is the situation when students become acquainted with important rituals and holidays in human life and their Christian versus secular meaning. For example, the importance of baptism and the welcoming of citizens are contrasted. In both cases it is a kind of welcome to society, in the case of baptism there is a clear spiritual overtone: in the Gospel of John (15:1-6) there is a parable of the vine and the branches where the meaning of baptism can be seen - that is, the individual becomes part of Jesus' body. Baptism can therefore be perceived in such a way that it is certainly not about removing bodily dirt, but about the good conscience to which we commit ourselves before God. (1Pt 3:21) Through Baptism, one does not only become a passive part of society but he is also given the opportunity to participate in the Good. Another example of enrichment may be ethical education where the emphasis is on the personality of a morally mature person who is pro-socially oriented, that is, who focuses on helping others or for their benefit. The spiritual overlap is that the main motive of help is the inner need of man, not the desire for reward. This corresponds to the abovementioned passage from the Bible (Lk 7:35-36) or the book of Proverbs (Prov 21:21): Whoever pursues righteousness and love finds life, prosperity and honor. The second area is the personal example and spiritual setting of academic staff. ${ }^{28}$ Roubalová ${ }^{29}$ states that a personal spiritual setting plays an important role in the process of educating and shaping students for their future vocation. Šarníková ${ }^{30}$ adds that the spiritual dimension of man is one of the signs of human transcendence and, besides one's parents, it is the educator who, by his example, awakens and develops this human dimension even in his students from pre-school age to adolescence. Chadima et al..$^{31}$ characterise traditional Christian education as a synergy of three basic factors: the principal story of Jesus Christ, the guarantee of the Church, and the presence of the family. At the same time, they admit that this is not so common nowadays, in postmodern times.

In connection with the issue addressed, the above statement can be used in order to trace a parallel which can create a framework for the spiritual dimension of the study programme. It means using the example of Jesus Christ and the presence of educators - those educators who will be

POTMĚŠILOVÁ et al., Olomouc: Univerzita Palackého v Olomouci, 2013, pp. 93-107.

28 In the case of academics at Sts Cyril and Methodius Faculty of Theology, the spiritual setting is perceived in terms of the Christian dimension.

29 Cf. Martina ORLOVSKÁ and Marcela ROUBALOVÁ, Učitelé a hodnoty - životní postoj učitele a předávání hodnot, in: Mládež a hodnoty 2010: Výchova k hodnotám v kontextu pluralitní a multikulturní společnosti, Jiří POSPÍŠIL and Marcela ROUBALOVÁ, Olomouc: Hanex, 2010, pp. 185-193.

30 Cf. Gabriela ŠARNÍKOVÁ, Budú cnosti v budúcnosti? O výchove k cnostiam, Ružomberok: Verbum, 2011, pp. 78-81, 171-176; cf. Gabriela ŠARNÍKOVÁ, Spiritualita dietała ako súčast̉ hladania pravdy o sebe a o svete, Predškolská výchova 4/2019, pp. 33-36.

31 Cf. Martin CHADIMA et al., Mezigenerační přenos základních křestanských hodnot v kontextu sekulární společnosti, Hradec Králové, 2015, pp. $84-85$. 
able to guarantee this transmission. The main question, and hence the incentive for the research, is whether the spiritual overlap of the Social Pedagogy Programme has been set, how this overlap is perceived by students, and (if it is present) whether its real impact on students can be traced.

\section{Research}

The research was realised with grant IGA_CMTF_2019_006. A quantitative methodology was chosen for the research. A questionnaire with ten items was used as a research tool. It was created by the author of this text and was distributed to the respondents in printed form.

\section{The Aim of the Research, Theoretical Background, and Hypotheses}

The aim of the research was to find out whether students are aware of the Christian dimension of the Social Pedagogy Programme at Sts Cyril and Methodius Faculty of Theology and whether this dimension is beneficial for them.

The theoretical starting points of the research was based on the data presented in Chapters 2 and 3:

1. The concept of social pedagogy in terms of help, of doing good.

2. Doing good for inner gratification and in accordance with Christian tradition.

Based on the theoretical background and the objective of the research, two research questions were identified:

V1: Do Social Pedagogy students perceive the Christian dimension of study at Sts Cyril and Methodius Faculty of Theology?

V2: Is the Christian dimension of study positively accepted by students?

The hypotheses were based not only on the research questions but also on the assumption that the student who chooses to study at Sts Cyril and Methodius Faculty of Theology knows about the specifics of such study. Based on these facts, the following hypotheses were established:

H1: There is no statistically significant link between the faith of students and the positive acceptance of the Christian dimension of study.

$\mathrm{H} 2$ : There is no statistically significant link between the faith of students and their awareness of the impact of the Christian dimension of study.

H3: There is no statistically significant link between the year of study and the awareness of the Christian dimension of study.

\section{Research Sample}

The research sample consisted of students of Social Pedagogy at Sts Cyril and Methodius Faculty of Theology who were enrolled in the academic year 2018/19. It was therefore a deliberate selection where each respondent had to meet the above criterion. In the academic year 2018/2019, 138 students were enrolled in all years and types of study according to the Study Agenda (STAG). In total, 122 completed questionnaires were returned, being almost $89 \%$.

All of these questionnaires were included in the research even though they were not completed in all the items. Of the total number $(\mathrm{N}=122), 113(97 \%)$ were women and $9(7 \%)$ were men. The age distribution of respondents ranged from 19 to 52. The average age of respondents was 28 and the most common age of respondents was 21 (12\%). 


\section{Methods of Data Analysis}

As mentioned above, the main method of data collection was a questionnaire survey. The data was rewritten into a table in Microsoft Excel. IBM SPSS 23 was used for statistical processing. ${ }^{32}$ Descriptive statistics of individual items were performed first. T-test for two independent samples, Analysis of variance (ANOVA), Kruskal-Wallis test, and the Pearson correlation coefficient were used to verify the validity of the hypotheses.

\section{Results}

The first four questions in the questionnaire concerned demographic data. The remaining questions were then focused on obtaining data regarding the students' attitudes towards their studies. At the beginning, the respondents were asked about their reason for choosing the study of Social Pedagogy at Sts Cyril and Methodius Faculty of Theology, Palacký University Olomouc. Students were allowed to select multiple choices thus the total number of responses does not match the number of respondents.

\begin{tabular}{|l|l|l|}
\hline Reason for choosing the study & Frequency & $\mathbf{\%}$ \\
\hline $\begin{array}{l}\text { I chose to study at Sts Cyril and Methodius Faculty because it is a theo- } \\
\text { logical faculty }\end{array}$ & 22 & 13 \\
\hline $\begin{array}{l}\text { My decision to study at Sts Cyril and Methodius Faculty was based on } \\
\text { recommendations }\end{array}$ & 31 & 19 \\
\hline $\begin{array}{l}\text { I chose to study at Sts Cyril and Methodius Faculty because of the offe- } \\
\text { red major }\end{array}$ & 97 & 59 \\
\hline I chose Sts Cyril and Methodius Faculty for another reason & 14 & 9 \\
\hline TOTAL & $\mathbf{1 6 4}$ & $\mathbf{1 0 0}$ \\
\hline
\end{tabular}

Tab. 1 Reason for their choice of study

Table 1 shows that $59 \%$ of responses were directly related to the study major. Also, 22 respondents stated that the reason for their choice was that the study major was offered at Sts Cyril and Methodius Theology Faculty.

Of the 122 respondents, $57 \%$ said that faith was not important in their lives while the remaining $43 \%$ said they perceived faith as an important part of their lives. A total of 10 respondents needed to clarify what they meant by faith: supernatural overlap, non-practising faith, spiritual forces in nature; and further specify what type of Christianity it is.

It was also investigated whether or not the number of subjects in which spiritual things are touched on by lecturers is satisfactory for students and whether these subjects suit them at all. 


\begin{tabular}{|l|l|l|}
\hline Item & Frequency & \% \\
\hline suits perfectly & 39 & 32 \\
\hline rather satisfying & 17 & 14 \\
\hline satisfying & 55 & 45 \\
\hline mostly dissatisfying & 11 & 9 \\
\hline does not suit at all & 0 & 0 \\
\hline (empty) & 0 & 0 \\
\hline TOTAL & $\mathbf{1 2 2}$ & $\mathbf{1 0 0}$ \\
\hline
\end{tabular}

Tab. 2 Number of courses

\begin{tabular}{|l|l|l|}
\hline Item & Frequency & $\mathbf{\%}$ \\
\hline suits perfectly & 32 & 26 \\
\hline rather satisfying & 20 & 16 \\
\hline satisfying & 57 & 47 \\
\hline mostly dissatisfying & 11 & 9 \\
\hline does not suit at all & 1 & 1 \\
\hline (empty) & 0 & 1 \\
\hline TOTAL & $\mathbf{1 2 1}$ & $\mathbf{1 0 0}$ \\
\hline
\end{tabular}

Tab. 3 Acceptance of subjects

It is apparent from both tables above that almost $50 \%$ of respondents stated that this type of subjects suited them and that the majority of students (respectively, almost $90 \%$ of respondents) agree not only with the subjects but also with their number. The Spearman correlation coefficient was used to determine the correlations between the two responses. Based on the calculated value $(\mathrm{r}=0.65, \mathrm{p}<0.01)$ it can be stated that the respondents answered both questions in the same manner.

Subsequently, the impact of spiritual subjects on personal, study, and work life was examined. Graph 1 shows the results of individual scales ${ }^{33}$ so that it is possible to compare respondents' answers in individual areas.

33 Respondents expressed the level of agreement with the item on a scale of 1-10 where 1 means complete agreement and 10 means complete disagreement (applies to Graphs 1 and 2). 


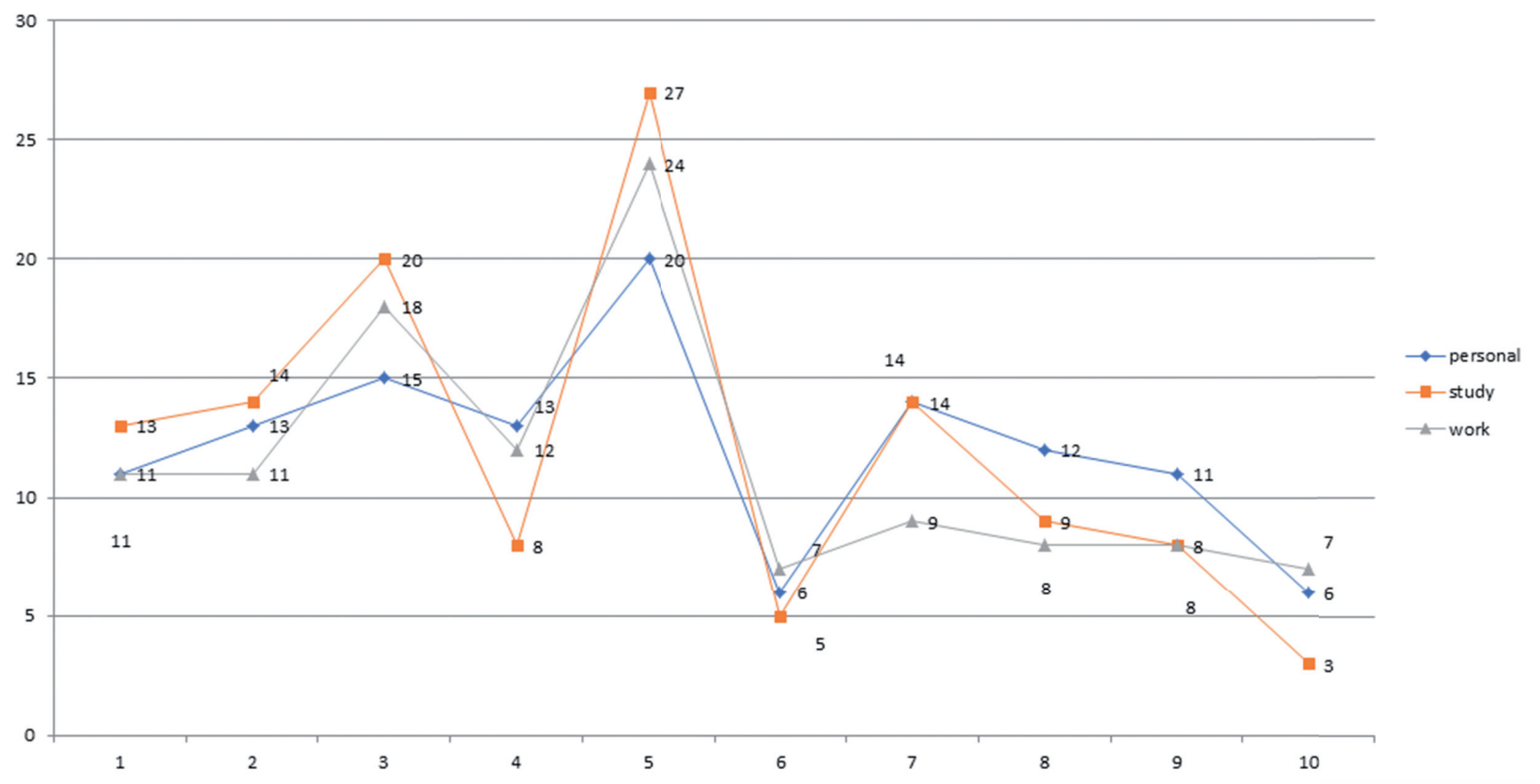

Graph 1 Impact of subjects

The relationship between these three impacts was again determined using the Spearman correlation coefficient. The calculated values show the relationship between personal and study significance $(\mathrm{r}=0.61, \mathrm{p}<0.01)$, personal and work significance $(\mathrm{r}=0.47, \mathrm{p}<0.01)$, and also between study and work significance $(r=0.52, \mathrm{p}<0.01)$. These data indicate that respondents answered identically in all three questions; if they perceived the importance of studying in one area, they perceived it in the others, and vice versa.

Another specific feature of the study of Social Pedagogy at Sts Cyril and Methodius Faculty is that the students encounter the fact that the academic staff do not conceal their faith but try to give an example to the students by their testimony. In addition, part of the academic staff are priests or nuns (consecrated persons), and students thus meet them regularly in the classroom. The following graph (Graph 2) shows data (teachers' faith $\mathrm{M}=3.22, \mathrm{SD}=1.75, \mathrm{MOD}=5, \mathrm{MED}=$ 3; presence of consecrated persons $\mathrm{M}=3.24, \mathrm{SD}=2.07, \mathrm{MOD}=1, \mathrm{MED}=3$ ). It can be observed that both specifics are accepted by students rather positively. 


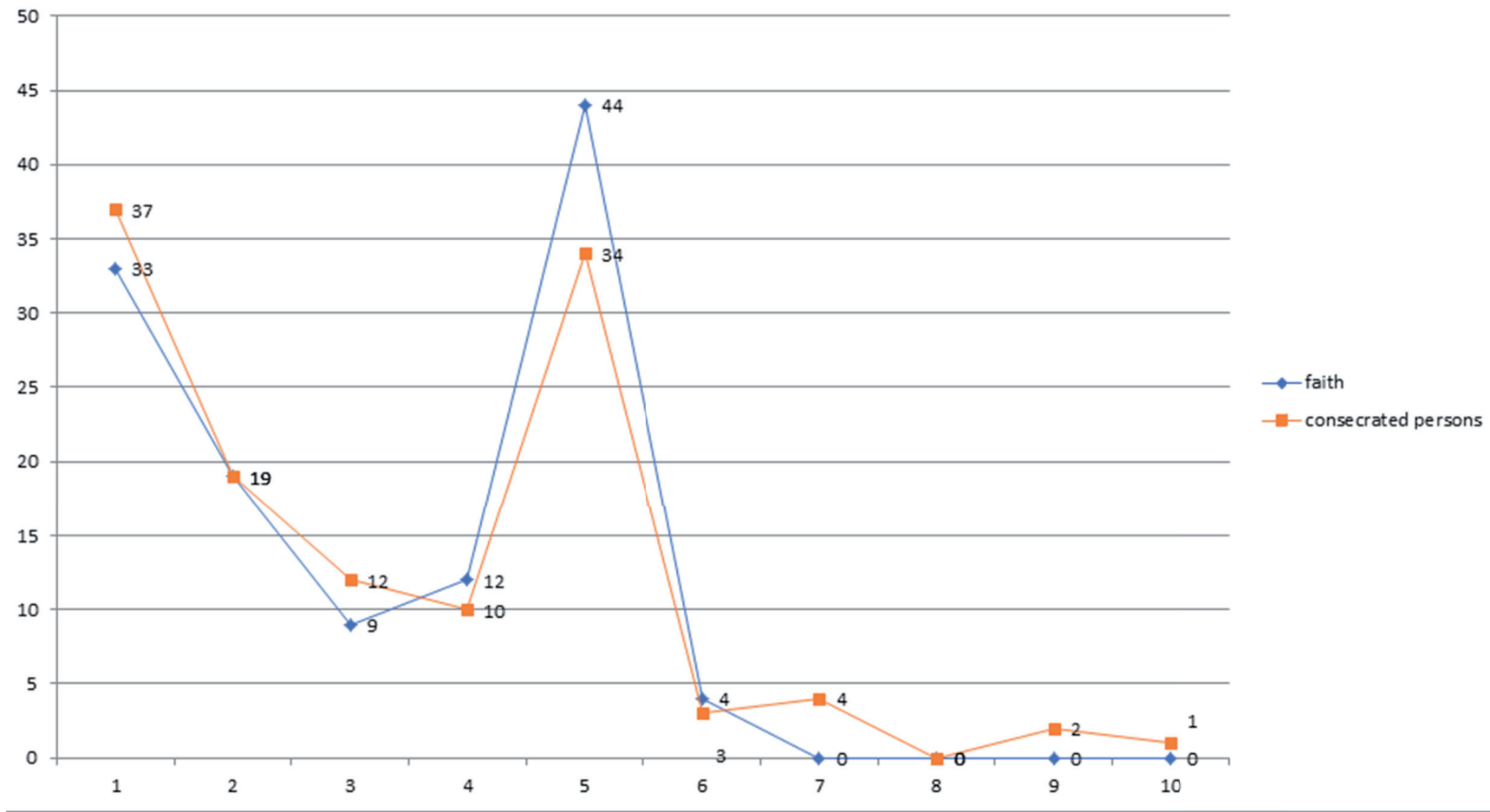

Graph 2 Influence of faith and consecrated persons

Answers to open questions raised statements on this issue... humanity, personal attitude, efforts to help ... personal attitude, greater willingness to help solve problems ... positive attitude of teachers.

\section{Validation of Hypotheses}

H1: There is no statistically significant link between the faith of students and the positive acceptance of the Christian dimension of study.

To test this hypothesis, answers were compared in which students commented on whether they were satisfied with the number of subjects and the subjects themselves, that is, the subjects where teachers touch the spiritual dimension. First, the mean values were calculated then the hypothesis was verified by means of the T-test for two independent samples. Table 4 gives an overview of what the average answer to these questions was (depending on whether or not faith is important in the students' lives).

\begin{tabular}{|l|l|l|l|l|}
\hline & Faith & Frequency & Average & Standard deviation \\
\hline Number & YES & 67 & 2.03 & 0.97 \\
\hline & NO & 51 & 2.67 & 0.97 \\
\hline Subjects & YES & 66 & 2.03 & 0.98 \\
\hline & NO & 51 & 2.86 & 0.85 \\
\hline
\end{tabular}

Tab. 4 


\begin{tabular}{|l|l|l|}
\hline T-test for two independent samples & Number & Subjects \\
\hline F & 1.52 & 9.60 \\
\hline Significance & 0.221 & 0.002 \\
\hline $\mathrm{t}$ & -3.53 & -4.84 \\
\hline $\mathrm{df}$ & 116 & 115 \\
\hline Significance & 0.001 & 0.000 \\
\hline Diameter difference & -0.64 & -0.83 \\
\hline Standard difference error & 0.18 & 0.17 \\
\hline
\end{tabular}

Tab. 5

The calculated data from both tables (Tables 4 and 5) show that it is possible to reject the null hypothesis ( $\mathrm{p}=0.001$, respectively 0.000 is $<0.01)$ and state that there is a statistically significant link between faith and the issue of whether students perceive the Christian dimension of study positively.

$\mathrm{H} 2$ : There is no statistically significant link between the faith of students and the awareness of the Christian dimension of study.

To test this hypothesis, the T-test for two independent samples was used to compare responses in which students expressed their perception of the importance of subjects with a spiritual dimension in their personal, study, and work area. Table 6 gives an overview of what the average answer to these questions was (depending on whether or not faith is important in the students' lives).

\begin{tabular}{|l|l|l|l|l|}
\hline & Faith & Number & Average & Standard deviation \\
\hline \multirow{2}{*}{$\begin{array}{l}\text { Meaning } \\
\text { in personal } \\
\text { area }\end{array}$} & YES & 66 & 3.82 & 2.20 \\
\cline { 2 - 5 } & NO & 61 & 6.81 & 2.30 \\
\hline $\begin{array}{l}\text { Meaning in } \\
\text { study area }\end{array}$ & YES & 67 & 3.85 & 2.18 \\
\cline { 2 - 5 } & NO & 50 & 5.82 & 2.52 \\
\hline $\begin{array}{l}\text { Meaning } \\
\text { in working } \\
\text { area }\end{array}$ & YES & 62 & 4.55 & 2.53 \\
\cline { 2 - 5 } & NO & 49 & 5.29 & 2.73 \\
\hline
\end{tabular}

Tab. 6

\begin{tabular}{|l|l|l|l|}
\hline T-test for two independent samples & $\begin{array}{l}\text { Meaning in perso- } \\
\text { nal area }\end{array}$ & $\begin{array}{l}\text { Meaning in study } \\
\text { area }\end{array}$ & $\begin{array}{l}\text { Meaning in work } \\
\text { area }\end{array}$ \\
\hline F & 0.47 & 1.61 & 0.09 \\
\hline Significance & 0.49 & 0.21 & 0.77 \\
\hline t & -7.15 & -4.53 & -1.47 \\
\hline df & 115 & 115 & 109 \\
\hline Significance & 0.000 & 0.000 & 0.144 \\
\hline
\end{tabular}




\begin{tabular}{|l|l|l|l|}
\hline Diameter difference & -2.99 & -1.99 & -0.74 \\
\hline Standard difference error & 0.42 & 0.44 & 0.50 \\
\hline
\end{tabular}

Tab. 7

From the calculated data from both tables (Tables 6 and 7) it can be said that in two cases (Meaning in personal area / $\mathrm{p}=0.000 /$ and Meaning in study area / $\mathrm{p}=0.000 /$ ) it is possible to reject the null hypothesis and it can be stated that there is a statistically significant link between faith and the issue of whether students are aware of the Christian dimension of study in relation to Meaning in the personal and study areas. In the case of the Meaning in work area, it is not possible to reject the null hypothesis ( $\mathrm{p}=0.144$ ), that is, there is no statistically significant difference between faith and awareness of the impact on employment.

H3: There is no statistically significant link between the year of study and the awareness of the Christian dimension of study.

To verify the hypothesis, the answers to the question about the importance of study for personal, study, and work life were compared with the year of study. Analysis of variance (ANOVA) and the Kruskal-Wallis test were used for testing the hypothesis.

\begin{tabular}{|c|c|c|c|c|c|c|}
\hline & & $\begin{array}{l}\text { Sum of squa- } \\
\text { res }\end{array}$ & df & $\begin{array}{l}\text { Average squa- } \\
\text { res }\end{array}$ & F & Significance \\
\hline \multirow{3}{*}{$\begin{array}{l}\text { Meaning } \\
\text { in perso- } \\
\text { nal area }\end{array}$} & $\begin{array}{l}\text { Between } \\
\text { groups }\end{array}$ & 57.50 & 4 & 14.37 & 2.08 & 0.09 \\
\hline & Inside groups & 801.83 & 116 & 6.91 & & \\
\hline & Total & 859.32 & 120 & & & \\
\hline \multirow{3}{*}{$\begin{array}{l}\text { Meaning } \\
\text { in study } \\
\text { area }\end{array}$} & $\begin{array}{l}\text { Between } \\
\text { groups }\end{array}$ & 33.14 & 4 & 8.29 & 1.33 & 0.27 \\
\hline & Inside groups & 723.73 & 116 & 6.24 & & \\
\hline & Total & 756.88 & 120 & & & \\
\hline \multirow{3}{*}{$\begin{array}{l}\text { Meaning } \\
\text { in work } \\
\text { area }\end{array}$} & $\begin{array}{l}\text { Between } \\
\text { groups }\end{array}$ & 66.81 & 4 & 16.70 & 2.60 & 0.04 \\
\hline & Inside groups & 709.48 & 110 & 6.45 & & \\
\hline & Total & 776.30 & 114 & & & \\
\hline
\end{tabular}

Tab. 8 Analysis of variance

\begin{tabular}{|l|l|l|l|}
\hline & $\begin{array}{l}\text { Meaning in personal } \\
\text { area }\end{array}$ & $\begin{array}{l}\text { Meaning in study } \\
\text { area }\end{array}$ & Meaning in work area \\
\hline Chi-square (X2) & 7.85 & 4.73 & 9.38 \\
\hline df & 4 & 4 & 4 \\
\hline Significance & 0.10 & 0.32 & 0.05 \\
\hline
\end{tabular}

Tab. 9 Kruskal-Wallis test 
From the results shown in Tables 8 and 9, it is evident that the null hypothesis in relation to Meaning in personal and study areas cannot be rejected. In the case of Meaning in work area, a statistically significant correlation with the year of study at the significance level of $0.05(\mathrm{p}=$ 0.04 , respectively 0.05 ) was shown. Thus, there is no statistically significant link between the year of study and the awareness of the Christian dimension of study at the personal and study levels, but at the work level it is. Pearson's correlation coefficient (Table 10) was used to find out more closely about the relationship between the year of study and the impact of the spiritual dimension of one's studies on the work area.

\begin{tabular}{|l|l|l|}
\hline & & Year of study \\
\hline \multirow{3}{*}{ Meaning in work area } & Pearson correlation coefficient & -0.29 \\
\cline { 2 - 3 } & Significance & 0.002 \\
\cline { 2 - 3 } & $\mathrm{N}$ & 115 \\
\hline
\end{tabular}

Tab. 10 Correlation of the year of study and Meaning in work area

From the data in the above table, it can be seen that at the significance level of $0.01(\mathrm{p}=0.002)$ correlations can be demonstrated between the year of one's studies and the impact of the spiritual dimension of the study on employment. The value of the correlation suggests that with the higher year of study, its positive impact increases.

\section{Discussion}

The aim of the research was to find out the students' perspective on the potential spiritual dimension of the Social Pedagogy study programme at Sts Cyril and Methodius Faculty, Palacký University Olomouc. Of the 122 respondents, less than half said that faith was important to their lives. In his research, Sak ${ }^{34}$ presents a ranking of the values of young people aged 19-30. Of 23 items, God is $22 \mathrm{nd}$. He also states that in 2001, about $32 \%$ of individuals claimed to believe in God. Prudk ${ }^{35}$ states that the orientation towards faith has changed significantly in the case of individuals in connection with the regime change in 1989. This phenomenon is called 'God after Communism. He states that at present ${ }^{36}$ there are up to $15 \%$ convinced believers. The present research shows a higher percentage of religious people, but this may be due to the environment of the theological faculty which, after all, attracts believers.

Baštecká and Goldmann ${ }^{37}$ cite Vymětal, who includes (besides meaningfulness, clarity, and coping) faith among the salutogenic elements. These are elements that are important in an individual's life; they fulfil a protective role. Neubauer draws attention to the crisis of Christianity and spiritual traditions. ${ }^{38}$ In this context, he subsequently states that the spiritual path is a general human need and is fundamentally inseparable from human nature. Halík ${ }^{39}$ considers religion to be a natural dimension of man and society, much like a sense of beauty, humour, or public life. Almost $90 \%$ of all respondents stated that they were satisfied with both the number of subjects and

34 Cf. Petr SAK and Karolína SAKOVÁ, Mládež na křižovatce, Praha: Svoboda Servis, 2004, pp. 11 and 35.

35 Cf. Libor PRUDKÝ et al, Inventura hodnot, Praha: Academie, 2009, p. 337.

36 Year of research 2001.

37 Cf. Bohumila BAŠTECKÁ and Petr GOLDMANN, Základy klinické psychologie, Praha: Grada, 2001, p. 293.

38 Cf. Zdeněk NEUBAUER, Smysl a duch, in: A nahoře nic..., Odilo ŠTAMPACH, Praha: Portál, 2000, p. 143.

39 Cf. Tomáš HALÍK, Co je bez chvění, není pevné, Praha: Nakladatelství lidové noviny, 2002, p. 28. 
their focus. Nevertheless, it has turned out that respondents who consider faith to be important in their lives perceive the meaning and number of subjects with spiritual themes more positively. Respondents also appreciate the behaviour and acting of academic staff.

When evaluating answers to questions about the possible impact of the Christian dimension of studies on personal, study, and working life, it has been shown that these answers correlate. It can therefore be said that the respondents answered the same way in all three cases. The mean values of responses to individual influences - personal $(\mathrm{M}=5.15, \mathrm{SD}=2.68, \mathrm{MOD}=5, \mathrm{MED}$ $=5)$, study $(\mathrm{M}=4.71, \mathrm{SD}=2.51, \mathrm{MOD}=5, \mathrm{MED}=5)$, and working life $(\mathrm{M}=4.92, \mathrm{SD}=2.61$, $\mathrm{MOD}=5, \mathrm{MED}=5$ ) - show that respondents chose their answers predominantly at the centre of the scale. The cumulative percentages also show that, on a 1-10 scale, 59.5\% of respondents voted between 1-5 in Meaning in personal area (67.8\% of respondents had the same results in Meaning in study area and $66.1 \%$ of them in Meaning in work area). This means that more than half of the respondents acknowledge the influence of the Christian dimension of study. In connection with faith, there was a correlation with a positive impact on their personal and study life. At this point, however, it is necessary to say that this is primarily a subjective statement of the respondents, that is, it is rather a feeling that the study influenced them. In addition to current students, the modified questionnaire was also sent to graduates. Of the total of 600 , only $16 \%$ of the questionnaires returned and all the answers were significantly positive: ... studying at 'our theological faculty' was the best life choice and a great experience... even during the admission procedure I felt like something 'breathed at me' and I wanted to get to this faculty at the time... I met great people here and I still have close relationships with them ... Theological faculty - the only choice for me! ... It gave me a lot for my personal and professional life. Since the questionnaire data cannot be considered objective, it was not included in the research.

Another question was whether the perception of the spiritual dimension of the study evolved with the year of study of the respondents. In this context, specific statements were often recorded: ${ }^{40} \ldots$ through the process I realise that it is actually a normal and pleasant environment ... a believer is quite normal and fine ... yeah, it's not a sect... The research showed only a connection with the year of study in the work area. It can be said that the students showed a statistically significant development in the perception of the spiritual dimension of the studies in connection with their employment. On the basis of all the above results it can be stated that, during their studies, students are increasingly aware of the positive influence of the spiritual dimension of the study in relation to their employment.

\section{Study Limits}

The basic limit of the study can be considered to be the fact that the objects of measurement are quantities that are difficult to measure. The research is thus based on mutual trust between the respondents and the researcher. The respondents communicate their subjective feelings that cannot be objectively confirmed. Another limit of the study can be the researcher who has a direct pedagogical impact on the respondents - students. The students were informed about the research in advance and were informed that they did not need to participate in the research. The obtained demographic data did not allow us to obtain the concrete identification of students, with the exception of the male students. Given their number, identification would probably be

40 These statements are pronouncements given by students of the Social Pedagogy programme. They were recorded on the basis of oral interviews with students during 2009-2019. 
possible. According to the answers to the open questions, where the respondents could write their own observations, it can be concluded that these reactions cannot be considered as purposeful. There are also negative reactions or criticisms in the answers: ... the content of some subjects is unbalanced ... a small number of non-theological C subjects ... some unnecessary subjects. Despite the above limits, conclusions can be made.

\section{Conclusion}

One of the pillars on which social pedagogical practice stands is solidarity, the ability to help those in need. Smékal ${ }^{41}$ states that, according to Rejnvaldová, one of the key personal characteristics is the pro-social orientation which can be characterised as the ability to perceive people's desires, willingness to cooperate, and the desire to bring joy and help to others. Solidarity and pro-social behaviour then fully correspond to the Christian principles of life which can be described by two commandments (Mk 12:30-31): ... And you shall love the LORD your God with all your heart, with all your soul, with all your mind, and with all your strength. ... You shall love your neighbor as yourself. The second refers to the need to be here for others as well. In connection with this, Halík ${ }^{42}$ adds that 'religion can be developed and cultivated, ... or remain on the edge of our lives, overshadowed by something else, or be completely neglected or even consciously suppressed'. One of the possibilities of development may be the study of Social Pedagogy which should lead, among other things, to the perception of the need to help others. In the case of spiritual overlap of the study programme, it should lead to selfless help to others which is motivated by the individual himself. The presented research has shown that students are subjectively perceiving the spiritual dimension of study and that they accept it positively but also that this perception intensifies with the period of study. It can therefore be stated that the spiritual dimension of the field of study (in our case, the Christian tradition) can be a significant enrichment of the Social Pedagogy programme. In open questions, students could answer which of the subjects had a positive impact on them. The most frequent subjects were the study of religions, the foundations of Christianity and the Christian in the contemporary world, and values and methodology of leisure activities - the spiritual dimension.

In the case of the subject study of religions, students encounter the basic characteristics of the main world religions. The two subjects, the foundations of Christianity and the Christian in the contemporary world, have the same content but the form is adapted to whether or not the students adhere to Christianity. The basic theme of these two subjects is the existential mystery of God and man. Within the framework of the value course, students have the opportunity to reflect upon the issue of the value orientation of today's man and upon the possibilities of strengthening positive values in the contemporary world. The practical subject methodology of leisure activities - the spiritual dimension shows students how to use a game as a means of conveying values or as a space for discussion about values. The seminar also includes pointing out the spiritual dimension of human life. Řiccan states that 'participation in the struggle between good and evil is for many people the centre of spiritual life. ${ }^{3}$

41 Cf. Vladimír SMÉKAL, Pozvání do psychologie osobnosti. Člověk v zrcadle vědomí a jednání, Brno: Společnost pro odbornou literaturu - Barrister \& Principal, 2009, p. 374.

42 HALÍK, Co je..., p. 28.

43 Pavel ŘíČAN, Psychologie náboženství a spirituality, Praha: Portál, 2007, p. 109. 


\section{Recommendations for Practice}

The study of Social Pedagogy at Sts Cyril and Methodius Faculty of Theology, Palacký University Olomouc has a declared added value in the form of a spiritual dimension which should manifest itself in two basic areas - enriching subjects with a Christian dimension and the actions of the academics, that is, giving an example for life. Based on the testimonies of the students, it appears that the students recognise this added value and evaluate it rather positively. For further work, it is advisable to describe (by means of a qualitative paradigm) how students perceive the impact of the spiritual dimension of their studies on their working life, that is, to describe their concrete idea, and to compare these statements with theoretical bases. Focusing on the students' personal development and its deepening can be considered a challenge (especially in the direction of pro-social behaviour and solidarity) as it may have a desirable impact on the concept of work settings in the field of socio-pedagogical practice in the spirit of the Bible's statement: Be shepherds of God's flock that is under your care, watching over them-not because you must, but because you are willing, as God wants you to be; not pursuing dishonest gain, but eager to serve; not lording it over those entrusted to you, but being examples to the flock (1Pt 5:2-3).

\section{Contact}

doc. PhDr. \& Mgr. Petra Potměšilová, Ph.D.

Palacký University Olomouc

Sts Cyril and Methodius Faculty of Theology, Department of Christian Education

Univerzitní 244/22, 77111 Olomouc

petra.potmesilova@upol.cz 